\title{
Vinyl Polymerization. CCCLXXXV. Polymerization of Methyl Methacrylate Initiated with Sodium Poly(L-glutamate) in Aqueous Medium of $\mathrm{Cu}(\mathrm{II})$ Ion
}

\author{
Tatsuro OUCHI, Kiyotaka WaTANABE, Toshiyuki YoshiKaWA, \\ Eijiro MORITA, and Minoru IMOTO \\ Department of Applied Chemistry, Faculty of Engineering, \\ Kansai University, Suita, Osaka 564, Japan.
}

(Received July 19, 1979)

\begin{abstract}
The polymerization of methyl methacrylate (MMA) by sodium poly(L-glutamate) (PLG-Na), copper(II) chloride and water was carried out. The effects of the $\mathrm{pH}$ of the aqueous solution and the mass of each component on the conversion were studied. The polymerization proceeded in an acidic medium through a radical mechanism. The initiation mechanism was discussed. The formation of the complex of $\mathrm{Cu}(\mathrm{II})$ ion with PLG-Na and water was confirmed by measurements of electric conductivity and UV spectrum of the PLG-Na aqueous solution in the presence of $\mathrm{CuCl}_{2}$.

KEY WORDS Sodium Poly(L-glutamate) / pH / Methyl Methacrylate / Copper(II) Chloride / Radical Polymerization / Initiation Mechanism / Electric Conductivity / UV Spectrum / Scanning Elecron Microscopy /
\end{abstract}

We reported that the macromolecules having the CONH group as main chain unit, such as silk, ${ }^{1}$ nylon $6,{ }^{2}$ nylon $3,{ }^{3} \alpha$-amylase, ${ }^{4}$ lysozyme, ${ }^{5}$ and poly $(\alpha-$ amino acid), ${ }^{6}$ were able to initiate the radical polymerization of methyl methacrylate (MMA) in an aqueous solution of metal ions, particularly, $\mathrm{Cu}(\mathrm{II})$ ions. The mechanism of the polymerization is considered to be as follows.
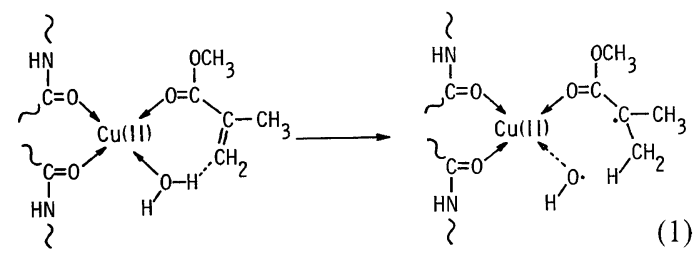

This paper is concerned with the radical polymerization of MMA initiated with the system of sodium poly(L-glutamate) PLG-Na, $\mathrm{Cu}(\mathrm{II})$ ion and water. PLG-Na contains CONH units and pendent carboxyl groups. The carboxyl groups are also expected to be active centers for the present uncatalyzed polymerization.

\section{EXPERIMENTAL}

\section{Materials}

PLG-Na afforded by Kyowa Hakko Co. Ltd., was used without further purification (molecular weight, $40,000-50,000$ ). MMA and other monomers were purified by the usual method and redistilled before use. Copper(II) chloride was of special commercial grade and used without further purification. Water was ion-exchanged and distilled.

\section{Procedures}

The polymerization was carried out in a sealed tube under vacuum, after thawing with nitrogen, with shaking at $85^{\circ} \mathrm{C}$ in the dark. After a definite time, the contents of the tube were poured into a large amount of methanol to precipitate the polymer. The collected polymer was thoroughly washed with methanol. By elemental analysis and IR, the polymer was confirmed to contain no PLG-Na and was regarded as homopoly(MMA). Thus, no grafted copolymerization of MMA onto PLG-Na was observed. The conversion was calculated by the following equation:

(weight of polymer/weight of feeded monomer) 
The number-average degrees of polymerization $\left(\bar{P}_{n}\right)$ of poly-MMA were calculated by Welch's equation, ${ }^{7}$ from $[\eta]$ measured at $30^{\circ} \mathrm{C}$ in benzene.

\section{Preparation of Buffer Solution}

Buffer solutions were prepared as follows: $\mathrm{pH} 2$, $(M / 10)$ sodium citrate- $(M / 10) \mathrm{HCl}$; pH 3-7, $(M / 10)$ citric acid- $(M / 5) \mathrm{Na}_{2} \mathrm{HPO}_{4} \cdot 12 \mathrm{H}_{2} \mathrm{O} ; \mathrm{pH} 8$, $(M / 15) \mathrm{Na}_{2} \mathrm{HPO}_{4} \cdot 12 \mathrm{H}_{2} \mathrm{O}-(M / 15) \mathrm{KH}_{2} \mathrm{PO}_{4} ; \mathrm{pH} 9$, $(M / 15) \mathrm{KH}_{2} \mathrm{PO}_{4}-(M / 20) \mathrm{Na}_{2} \mathrm{~B}_{4} \mathrm{O}_{7} \cdot 10 \mathrm{H}_{2} \mathrm{O} ; \mathrm{pH} 10$, $(M / 20) \mathrm{Na}_{2} \mathrm{~B}_{4} \mathrm{O}_{7} \cdot 10 \mathrm{H}_{2} \mathrm{O}-(M / 10) \mathrm{NaOH} ; \mathrm{pH} 11$, $(M / 10) \mathrm{NaOH}-(M / 10) \mathrm{Na}_{2} \mathrm{HPO}_{2} \cdot 12 \mathrm{H}_{2} \mathrm{O}$.

\section{RESULTS AND DISCUSSION}

Effect of $p H$ of the Aqueous Solution on the Conversion of $M M A$

The polymerizations of MMA with PLG-Na were carried out at various $\mathrm{pH}$ in the aqueous solution. $\mathrm{pH}$ adjustments were made by the buffer solutions. As can be seen in Figure 1, the polymerization took place only in an acidic medium but not in neutral or basic media.

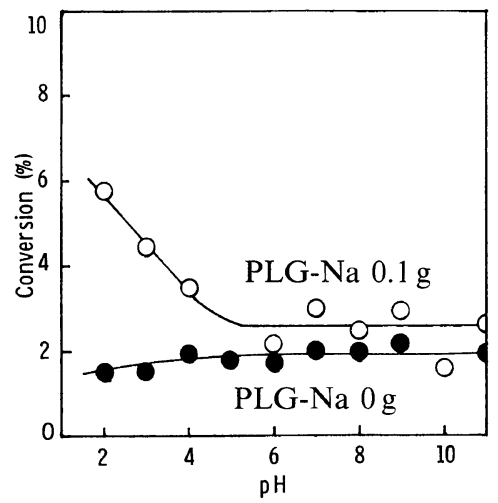

Figure 1. Conversion of MMA vs. $\mathrm{pH}$ of the aqueous solution: MMA, $5 \mathrm{~cm}^{3} ; \mathrm{CuCl}_{2} \cdot 2 \mathrm{H}_{2} \mathrm{O}, 5 \times 10^{-4} \mathrm{~g}$; buffer solution, $10 \mathrm{~cm}^{3} ; 85^{\circ} \mathrm{C} ; 5 \mathrm{~h}$.

The ineffectiveness of PLG-Na in alkaline and neutral media is considered due to the following three reactions.

i) PLG-Na is known to form an $\alpha$-helix conformation more easily than poly(L-glutamic acid) (PLGA). ${ }^{8}$

On the other hand, Fujie and Kawai ${ }^{9}$ studied the polymerization of MMA at $70^{\circ} \mathrm{C}$ in the presence of $\operatorname{poly}(\alpha$-amino acid $)$ and copper(II) ion and found that if poly $(\alpha$-amino acid) has the $\alpha$-helix conformation, the polymerization does not proceed, and in the cases of the random coil and $\beta$-conformations the polymerization occurs to a greater extent. These results are due to the ease of formation of the $\mathrm{Cu}(\mathrm{II})$ ion complex with $\operatorname{poly}(\alpha$-amino acid $)$ having the $\beta$ conformation. Accordingly, in the present case, the formation of an adequate complex of $\mathrm{Cu}(\mathrm{II})$ ion with PLG-Na becomes more difficult than that with PLGA.

ii) As described in an earlier section, even if PLG-Na can bind with $\mathrm{Cu}(\mathrm{II})$ ion, the composition of the complex becomes that of $(\mathrm{Glu})_{3} \mathrm{Cu}(\mathrm{II})$, which has no capacity to initiate the polymerization.

iii) As will be shown later by scanning electron microscopy, PLG-Na cannot form any hydrophobic areas.

Hereinafter, the polymeizations were carried out in the aqueous solution buffered at $\mathrm{pH} 2$.

\section{Effect of the Mass of Cu(II) Ion on the Conversion of $M M A$}

Figure 2 shows the effect of the mass of $\mathrm{Cu}(\mathrm{II})$ ion on the conversion of MMA. As can be seen, in the case of $\mathrm{pH} 2$, a maximum conversion of MMA was obtained at $5 \times 10^{-4} \mathrm{~g}$ of $\mathrm{CuCl}_{2} \cdot 2 \mathrm{H}_{2} \mathrm{O}$. From the figure, it was concluded that the $\mathrm{Cu}(\mathrm{II})$ ion could promote the polymerization of MMA.

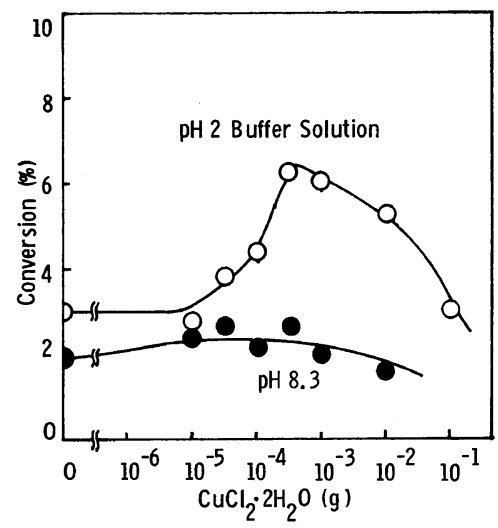

Figure 2. Conversion of MMA vs. mass of copper(II) chloride: MMA, $5 \mathrm{~cm}^{3}$, PLG-Na $0.1 \mathrm{~g}$; aqueous solution, $10 \mathrm{~cm}^{3} ; 85^{\circ} \mathrm{C} ; 5 \mathrm{~h}$.

\section{Selectivity for Vinyl Monomer}

In order to observe the selectivity for vinyl monomer in the polymerization, by PLG-Na,copper(II) chloride, with a $\mathrm{pH} 2$ buffer solution, polymeri- 
zations of three kinds of vinyl monomer were carried out.

As shown in Table I, the polymerization of MMA was accelerated by PLG-Na in the $\mathrm{pH} 2$ buffer solution containing $\mathrm{Cu}(\mathrm{II})$ ion, while the polymerization of styrene (ST) and acrylonitrile (AN) were not.

Table I. Selectivity of vinyl monomer ${ }^{a}$

\begin{tabular}{cccc}
\hline & \multicolumn{3}{c}{ Conversion/\% } \\
\cline { 2 - 4 } PLG-Na/g & MMA & ST & AN \\
\hline 0.1 & 6.20 & 4.34 & 0.82 \\
0 & 1.49 & 3.77 & 0.68 \\
\hline
\end{tabular}

a Vinyl monomer, $5 \mathrm{~cm}^{3} ; \mathrm{CuCl}_{2} \cdot 2 \mathrm{H}_{2} \mathrm{O}, 5 \times 10^{-4} ; \mathrm{pH} 2$ buffer solution, $10 \mathrm{~cm}^{3} ; 85^{\circ} \mathrm{C}, 5 \mathrm{~h}$.

\section{Proof of Radical Mechanism}

In order to confirm that polymerization proceeded through a radical mechanism, copolymerizations of $\operatorname{MMA}\left(\mathrm{M}_{1}\right)$ with $\mathrm{ST}\left(\mathrm{M}_{2}\right)$ were carried out and the results are shown in Figure 3. From the curve, $r_{1}$ and $r_{2}$ were calculated to be 0.57 and 0.56 , respectively. A radical mechanism was verified from these results.

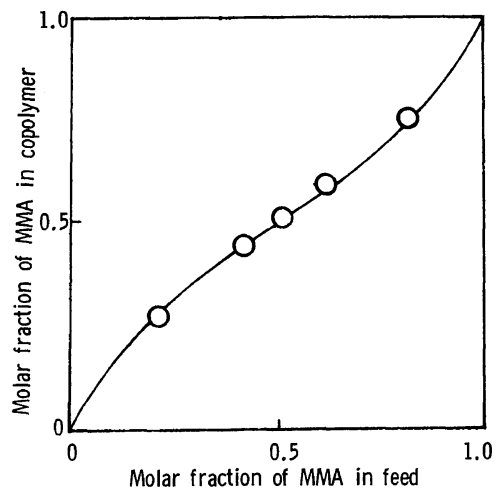

Figure 3. Copolymerization of MMA with $\mathrm{St}$ : (MMA+ST); $3 \mathrm{~cm}^{3}$, PLG-Na $0.1 \mathrm{~g} ; \mathrm{CuCl}_{2} \cdot 2 \mathrm{H}_{2} \mathrm{O}$, $5 \times 10^{-4} \mathrm{~g} ; \mathrm{pH}, 2$ buffer solution, $10 \mathrm{~cm}^{3} ; 85^{\circ} \mathrm{C} ; 5 \mathrm{~h}$.

Effect of the Amount of MMA on the Polymer Yield Keeping the concentration of PLG-Na and $\mathrm{CuCl}_{2} \cdot 2 \mathrm{H}_{2} \mathrm{O}$ constant, and varying the mass of MMA, polymerizations were carried out. The effect of the mass of MMA on the polymer yield and $\bar{P}_{n}$ of poly(MMA) were shown in Figure 4. The corrected

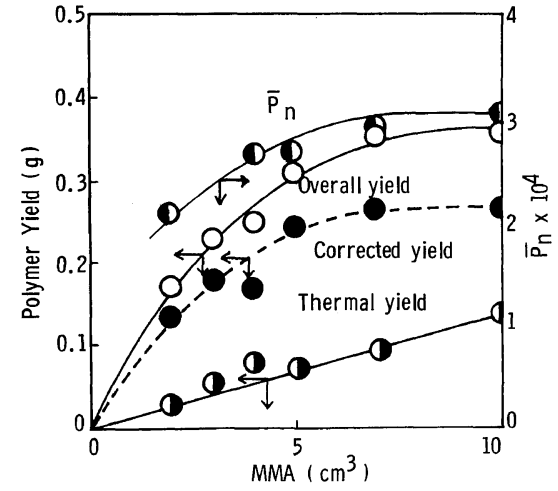

Figure 4. Effect of the mass of MMA on the polymer yield: $\mathrm{CuCl}_{2} \cdot 2 \mathrm{H}_{2} \mathrm{O}, 5 \times 10^{-4} \mathrm{~g}$; $\mathrm{pH} 2$ buffer solution, 10 $\mathrm{cm}^{3} ; 85^{\circ} \mathrm{C} ; 5 \mathrm{~h}$; PLG-Na, $0.1 \mathrm{~g}(\mathrm{O}, \bigcirc, \bigcirc)$ and $0 \mathrm{~g}(()$ ).

yield, estimated by deducting the thermal yield from the overall yield, became independent of the mass of MMA, beyond a certain period in which the polymer yield increased with the mass of MMA. Such a figure is usually obtained in the "uncatalyzed polymerization" of MMA initiated with macromolecule. On the other hand, $\bar{P}_{n}$ of poly(MMA) increased up to a certain mass of MMA, and became independent beyond that mass.

\section{Effect of the Mass of PLG-Na on the Conversion of $M M A$}

The results obtained in the study of the effect of the mass of PLG-Na on the polymerization of MMA are shown in Figure 5. In this figure, a remarkable observation was the decrease in the conversion of

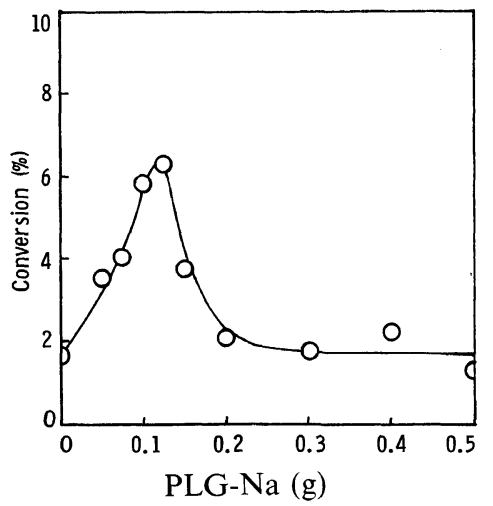

Figure 5. Conversion of MMA $v s$. mass of PLG-Na: MMA, $5 \mathrm{~cm}^{3} ; \mathrm{CuCl}_{2} \cdot 2 \mathrm{H}_{2} \mathrm{O}, 5 \times 10^{-4} \mathrm{~g} ; \mathrm{pH} 2$ buffer solution, $10 \mathrm{~cm}^{3} ; 85^{\circ} \mathrm{C} ; 5 \mathrm{~h}$. 
MMA when the dissolved mass of PLG-Na exceeded a certain limit. Such a phenomenon was also recognized in the polymerization of MMA in the aqueous starch solution. ${ }^{10}$ Such a decrease in the

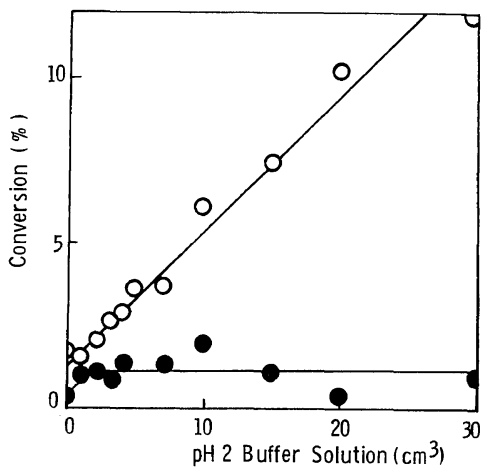

Figure 6. Conversion of MMA vs. added volume of PLG-Na solution: MMA, $5 \mathrm{~cm}^{3} ; \mathrm{CuCl}_{2} \cdot 2 \mathrm{H}_{2} \mathrm{O}, 5 \times 10^{-4}$ $\mathrm{g} ; 85^{\circ} \mathrm{C} ; 5 \mathrm{~h}$. $\bigcirc$, the $\mathrm{pH} 2$ buffer solution containing $10^{-2} \mathrm{~g} \mathrm{dm}^{3}$ of PLG-Na; 0 , the $\mathrm{pH} 2$ buffer solution containing no PLG-Na.

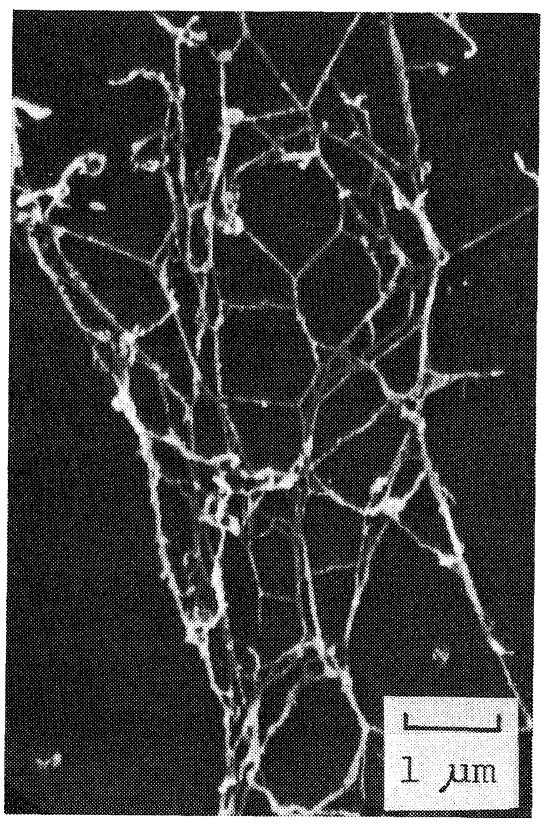

(A) $\mathrm{pH} 8.3$ conversion is considered due to the increased entanglement of PLG-Na molecules, making formation of adequeate hydrophobic areas (HA) difficult. MMA are incorporated into the HA and there the polymerization commences.

Thus by maintaining the concentration of PLG$\mathrm{Na}$ solution at $10^{-2} \mathrm{~g} \mathrm{dm}^{3}$, and changing the added volume of PLG-Na solution, the polymerization of MMA was carried out. The results obtained in Figure 6 show that the conversion of MMA increased linearly with the added volume of PLG-Na solution; this figure supports the considerations mentioned above.

\section{Surface View of Polymerization System by Electron Microscopy}

Direct evidence of the formation of HA was obtained by scanning electron microscopy (SEM). The SEM procedure was the same as that reported in a previous paper. ${ }^{10}$ In Figure 7(B), the formation of HA can be observed. However, it is clear that in the case of Figure 7(A), HA is not formed.

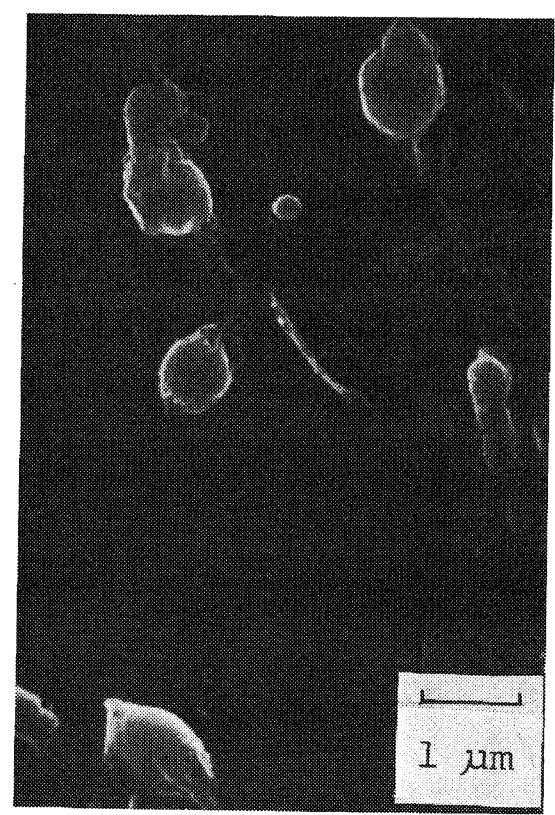

(B) $\mathrm{pH} 2$

Figure 7. Surface views of PLG-Na in $\mathrm{pH} 8.3$ and 2.

(A) $0.1 \mathrm{~g}$ of PLG-Na was dissolved in $10 \mathrm{~cm}^{3}$ of water containing $5 \times 10^{-4} \mathrm{~g}$ of $\mathrm{CuCl}_{2} \cdot 2 \mathrm{H}_{2} \mathrm{O}$, warmed at $85^{\circ} \mathrm{C}$ for $3 \mathrm{~h}$ and diluted with $1 \mathrm{dm}^{3}$ of $\mathrm{H}_{2} \mathrm{O}$.

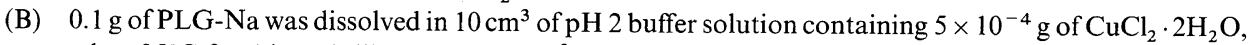
warmed at $85^{\circ} \mathrm{C}$ for $3 \mathrm{~h}$ and diluted with $1 \mathrm{dm}^{3}$ of $\mathrm{H}_{2} \mathrm{O}$. 


\section{Mechanism of Initiation}

In order to study the necessity of PLG-Na as a macromolecule, monomeric glutamic acid and sodium glutamate were used, instead of PLG-Na. As listed in Table II, glutamic acid and sodium glutamate could not initiate the polymerization of MMA. Thus, it was confirmed that the uncatalyzed polymerization could be initiated only by a macromolecule.

To confirm the formation of the complex of $\mathrm{Cu}$ (II) ion with PLG-Na, electrical conductivity and UV spectra were measured by a Yanagimoto conductometer (Type MY-8) and a Simadzu double beam spectrophotometer (Type UV-200), respectively.

Table II. Polymerization of MMA in the presence of Glu compound ${ }^{\mathrm{a}}$

\begin{tabular}{lcc} 
& \multicolumn{2}{c}{ Conversion $/ \%$} \\
\cline { 2 - 3 } Glu compound & $\begin{array}{c}\text { In pH 2 buffer } \\
\text { solution }\end{array}$ & In water (pH 8.3) \\
& 6.20 & 3.04 \\
PLG-Na & 1.93 & 0.65 \\
Glutamic acid & 1.81 & 1.30 \\
Sodium glutamate & & \\
\hline
\end{tabular}

a MMA, $5 \mathrm{~cm}^{3}$; glutamic acid compound, $6.62 \times 10^{-4}$ mol; $\mathrm{CuCl}_{2} \cdot 2 \mathrm{H}_{2} \mathrm{O} 5 \times 10^{-4}$; aqueous solution, $10 \mathrm{~cm}^{3}$; $85^{\circ} \mathrm{C} ; 5 \mathrm{~h}$

Figure 8 shows the results of electrical conductivity. From this figure, it is clear that the $\mathrm{Cu}(\mathrm{II})$ ion is bonded to PLG-Na.

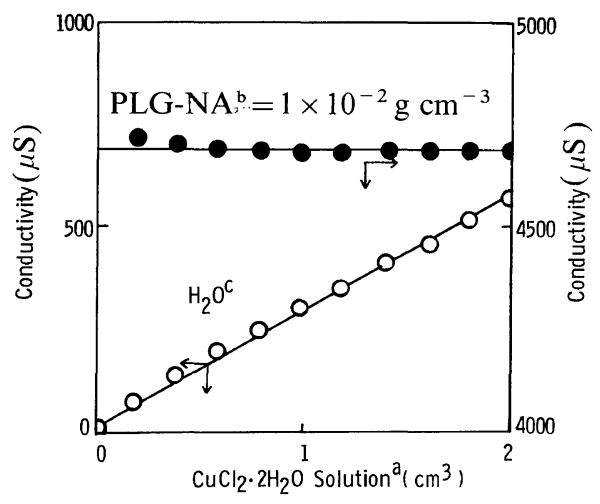

Figure 8. Electrical conductivity of $\mathrm{CuCl}_{2}$ in aqueous PLG-Na solution at room temperarure.

a $\left[\mathrm{CuCl}_{2}\right]=3 \times 10^{-3} \mathrm{~g} \mathrm{dm}^{-3}$.

b $30 \mathrm{~cm}^{3}$ of PLG-Na at $1 \times 10^{-3} \mathrm{~g} \mathrm{dm}^{-3}$.

c $30 \mathrm{~cm}^{3}$ of $\mathrm{H}_{2} \mathrm{O}$.

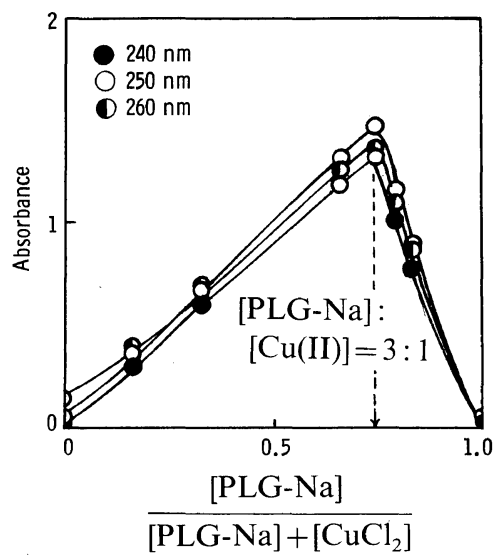

Figure 9. Analysis by the continuous variation method in water $(\mathrm{pH} 8.3) ;[\mathrm{PLG}-\mathrm{Na}]=\left[\mathrm{CuCl}_{2}\right]=1.16 \times 10^{-3}$ $\mathrm{mol} \mathrm{cm} \mathrm{c}^{-3}$, in $\mathrm{H}_{2} \mathrm{O}$ at room temperature.

Moreover, the results of UV spectra obtained by continuous variation method are shown in Figure9. As can be seen in this figure, the maximum absorbance in water ( $\mathrm{pH} 8.3)$ appeared at the mole ratio of $1: 3$ of $\mathrm{Cu}(\mathrm{II})$ : unit of PLG-Na; the complex of ratio of $1: 3$ was suggested to be formed; three coordination sites of $\mathrm{Cu}$ (II) ion are considered to be filled, as shown in following structure. The initiation mechanism in the present polymerization can be written as eq 1 . Since, in the $\mathrm{pH} 8.3$ medium, it was difficult to keep open vacant sites for MMA and water, the complex lost its catalytic activity, as was reported in the case of using nylon $3 .^{3}$

\section{Polymerization by PMAA}

In order to find out directly the action of the

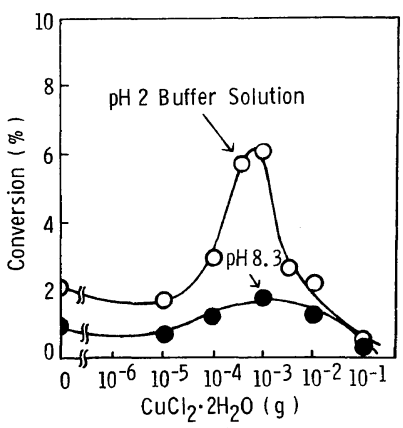

Figure 10. Polymerization of MMA with PMAA: MMA, $5 \mathrm{~cm}^{3}$; PMAA-Na $0.0835 \mathrm{~g}$; aqueous solution, 10 $\mathrm{cm}^{3} ; 85^{\circ} \mathrm{C} ; 5 \mathrm{~h}$. 
COONa group, the polymerization of MMA was carried out using sodium poly(methacrylic acid) (PMAA) whose main chain consists of $\mathrm{CH}_{2}-\mathrm{C}\left(\mathrm{CH}_{3}\right)$ bonds. The results obtained are shown in Figure 10. from this figure, it is clear that PMAA has the ability to initiate polymerization.

Therefore, in the case of using PLG-Na, the polymerization of MMA is also considered to be initiated by a mechanism (2) other than the mechanism (1) described above.

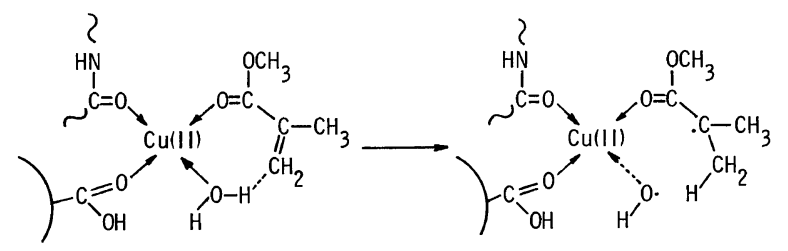

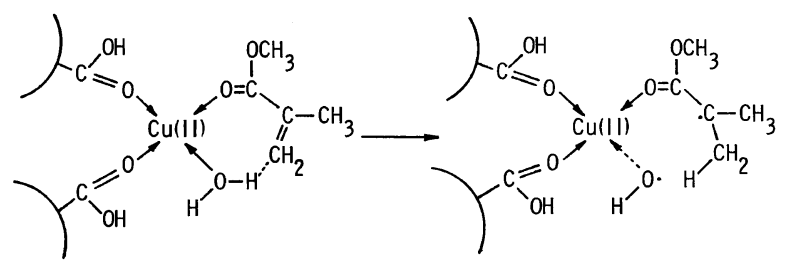

\section{REFERENCES}

1. M. Imoto, K. Takemoto, and M. Kondo, Makromol. Chem., 104, 244 (1967); M. Imoto, K. Takemoto, H. Azuma, N. Kita, and M. Kondo, Makromol. Chem., 107, 188 (1967).

2. M. Imoto, A. Tanaka, K. Ueno, and K. Takemoto, Angew. Makromol. Chem., 18, 55 (1971).

3. T. Ouchi, T. Nishimura, and M. Imoto, J. Polym. Sci. Polym. Chem. Ed, 14, 2695 (1976); T. Nishimura, T. Ouchi, and M. Imoto, Makromol. Chem., 177, 1895 (1976).

4. M. Imoto, N. Sakade, and T. Ouchi, J. Polym. Sci.
Polym. Chem. Ed., 15, 499 (1977).

5. T. Ouchi, T. Yoshikawa, and M. Imoto, J. Macromol. Sci. Chem., A12, 1523 (1978).

6. M. Imoto, T. Nishimura, N. Sakade, and T. Ouchi, Chem. Lett., 1119 (1975).

7. F. J. Welch, J. Polym. Sci., 61, 243 (1962).

8. S. Inoue, K. Yamaoka, and M. Miura, Bull. Chem. Soc. Jpn., 45, 1314 (1972).

9. A. Fujie and T. Kawai, Makromol. Chem., 176, 629 (1975).

10. M. Imoto, E. Morita, and T. Ouchi, J. Polym. Sci. Polym. Symp., in press. 